\title{
Structural variations in remnants of Mixed Ombrophilous Forest in the extreme South of Brazil
}

\author{
Variaciones estructurales en remanentes de bosque umbrófilo mixto \\ en el extremo sur de Brasil
}

\author{
Daniele Guarienti Rorato a, Maristela Machado Araujo b, Adriana Maria Griebeler ${ }^{\text {b*, }}$

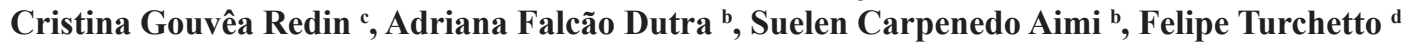 \\ a Parana State West University, Department of Agronomy, Marechal Candido Rondon, Brazil. \\ *Corresponding author: ${ }^{\mathrm{b}}$ Federal University of Santa Maria, Department of Forest Sciences, \\ Santa Maria, Brazil, tel.: +55 553220 8276, griebeleradriana@gmail.com \\ c Santa Catarina West University, Department of Forestry Engineering, Xanxerê, Brazil. \\ ${ }^{\mathrm{d}}$ Federal University of Santa Maria, Department of Forest Engineering, Frederico Westphalen, Brazil.
}

\begin{abstract}
SUMMARY
The study aimed at characterizing the arboreal-shrubby component in fragments of Mixed Ombrophilous Forest, in Rio Grande do Sul State, Brazil. The vegetation survey was performed in four sampled fragments in 57 plots. In the plots, the identification of the individuals and measurement of circumference at breast height (CAP) was carried out, according to the following classes of size: Class I) arboreal strata, individuals with CAP $\geq 30 \mathrm{~cm}(10 \times 20 \mathrm{~m})$; Class II) arboreal strata, individuals with $15 \leq \mathrm{CAP}<30 \mathrm{~cm}(10$ x $10 \mathrm{~m})$; Class III) established natural regeneration, individuals with $3 \leq \mathrm{CAP}<15 \mathrm{~cm}(5 \mathrm{x} 5 \mathrm{~m})$ and Class IV) bank of seedlings, individuals with height $\geq 30 \mathrm{~cm}$ and CAP $<3 \mathrm{~cm}(2 \times 2 \mathrm{~m})$. The data of Class I constituted a matrix parcel $\mathrm{x}$ species, which was used in a multivariate analysis, allowing the classification of groups of plots that characterize microhabitats. The forest fragments presented low floristic richness of typical species of Mixed Ombrophilous Forest. From this environment highlight two main groups, one characteristic of riparian forest and the other from capões. In the riparian forests (GR1), highlighted Eugenia uruguayensis and Gymnanthes klotzschiana. In capões (GR2), the predominant species were Araucaria angustifolia, Podocarpus lambertii and Myrceugenia cucullata. The condition of species in different classes associated with their ecological characteristics allows identifying possible strategies for perpetuation of the arboreal-shrubby component of population and management of the fragments aiming at its conservation.
\end{abstract}

Key words: phytosociology, TWINSPAN, floristic cluster, multivariate analysis.

\section{RESUMEN}

El estudio tuvo como objetivo caracterizar el componente arbóreo-arbustivo en fragmentos de Bosque Umbrófilo Mixto. El relevamiento de la vegetación se realizó en cuatro fragmentos muestreados en 57 parcelas. Se identificaron los individuos y se midió la circunferencia a la altura del pecho (CAP), considerando las siguientes clases: Clase I) estrato arbóreo, CAP $\geq 30 \mathrm{~cm}(10 \mathrm{~m} \times 20 \mathrm{~m}$ ); Clase II) estrato arbóreo, $15 \leq \mathrm{CAP}<30 \mathrm{~cm}(10 \mathrm{~m}$ x $10 \mathrm{~m})$; Clase III) regeneración natural establecida, $3 \leq \mathrm{CAP}<15 \mathrm{~cm}(5 \mathrm{~m} \times 5 \mathrm{~m})$ y clase IV) banco de plántulas, altura $\geq 30 \mathrm{~cm}$ y CAP $<3 \mathrm{~cm}(2 \mathrm{~m} \mathrm{x} 2 \mathrm{~m})$. Los datos del estrato arbóreo (Clase I) constituyeron una matriz de parcela x especie, la cual fue utilizada en análisis multivariado, permitiendo la clasificación de grupos de parcelas que caracterizan a los microhábitats. Los fragmentos de bosque en cumbres de la sierra presentaron baja riqueza florística de especies típicas del Bosque Umbrófilo Mixto. De este ambiente típico, se destacan dos grupos principales, uno característico de bosques de galería y el otro de bosques en islas (capões). En los bosques de galería (GR1), destacaron Eugenia uruguayensis y Gymnanthes klotzschiana. En los bosques en islas (GR2), las especies predominantes fueron Araucaria angustifolia, Podocarpus lambertii y Myrceugenia cucullata. La condición de especies en las diferentes clases asociadas a sus características ecológicas permite identificar posibles estrategias para perpetuar el componente arbóreo-arbustivo de las poblaciones y de fragmentos buscando su conservación.

Palabras clave: fitosociología, TWINSPAN, agrupación florística, análisis multivariado. 


\section{INTRODUCTION}

The Atlantic Forest Biome occupies $15 \%$ of the Brazilian territory and presents a variety of formations, among them the Mixed Ombrophilous Forest or Araucaria Moist Forest, which is considered one of the main formations of the South Region of Brazil (Higuchi et al. 2012). Nevertheless, the constant anthropic action in these environments, caused by the expansion of areas with agriculture and livestock, as well as the planting of Pinus and Eucalyptus genera, resulted in the fragmentation and degradation of these ecosystems. As consequence, currently, this formation is considered one of the most threatened phytophysiognomies among the forest formations of the country, remaining only $7 \%$ of the original cover (Vibrans et al. 2012).

The High Altitude Fields, also known as Campos de Cima da Serra, are found in the extreme South of Brazil, in the region of Brazilian South Plateau. This vegetation forms, frequently, mosaics with the Mixed Ombrophilous Forest, characterizing a forest-field transition system, strongly influenced by human activities (Pillar et al. 2009). In these places, studies are necessary, taking into account the phytosociological aspects of the forest community. This can be performed by means of multivariate techniques such as the cluster analysis, seeking to identify the groups of species that share similar environmental affinities and usually occupy the same places in a determined landscape (Adel et al. 2014). This way, these can be used to indicate environmental complexes, based on the presence and abundance of different indicator species (Goebel et al. 2001).

In this sense, identifying the formation of cluster of species constitutes itself in an important tool used to classify vegetation, as well as a source of information about the spatial distribution of the same (Pajares and Rosselo 1995). Therefore, the knowledge of the phytosociological behavior of natural populations, associated with the information about the structure, allows inferring about the conservation strategies of species, as well as subsidizing information for the ecosystem management, enrichment and/or recovering of changed areas (Dengler et al. 2008).

According to what exposed before, the aim of the study is to characterize the arboreal-shrubby component of remnants of Mixed Ombrophilous Forest. Sought to answer the following questions: a) what is the current situation of vegetation in the studied fragments? b) do these fragments form cluster in the arboreal component of vegetation? c) which species is responsible for the main existent formation(s)? d) is it possible to identify strategies of management by means of phytosociology in a catalogue of a single occasion?

\section{METHODS}

The area of study is located in Sao Francisco de Paula, Rio Grande do Sul State, Brazil (29 $17^{\prime} 56^{\prime \prime} \mathrm{S}$ and 50 $34^{\circ}$ 12 " W), average altitude of $907 \mathrm{~m}$ (figure 1). The climate

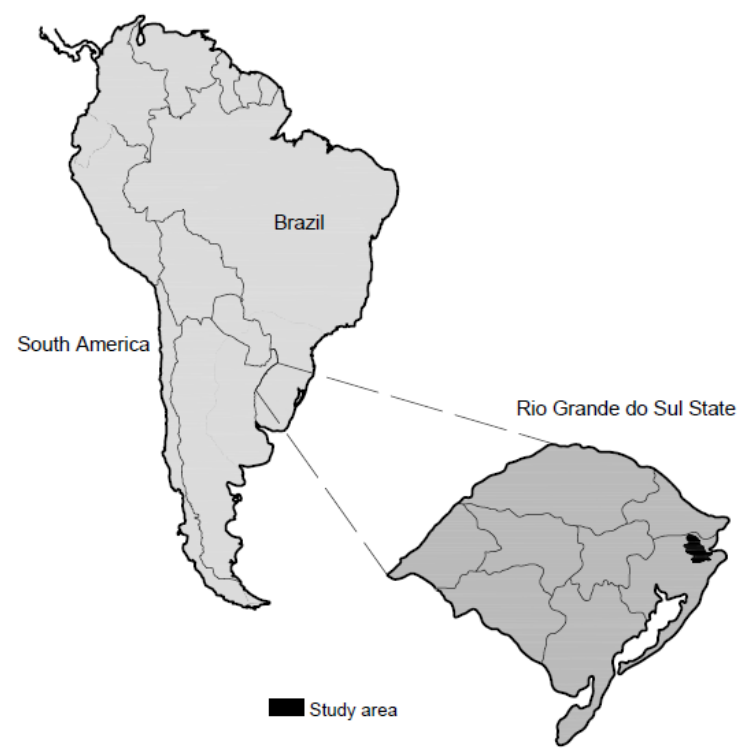

Figure 1. Geographical location of the study area in the state of Rio Grande do Sul State, Brazil.

Localización geográfica del área de estudio en el estado de Rio Grande do Sul, Brasil.

of the region is classified as subtropical, of fundamental type $\mathrm{Cfb}$ (Alvares et al. 2013) and the dominant soils in the region were classified by Streck et al. (2008) as Cambisols and Neosols. The region is called as Campos de Cima da Serra, in which the fields form mosaics with the Mixed Ombrophilous Forest, characterizing systems of forestfield transition (Pillar et al. 2009).

The survey of vegetation was performed in four forest fragments, denominated as Fragment 1 ( 9 ha, with 17 plots), Fragment 2 ( 9 ha, with 14 plots), Fragment 3 ( 2 ha, with 7 plots) and Fragment 4 (9 ha, with 19 plots), totalizing 57 plots.

In the vegetation survey of the arboreal and shrubby component were established four classes of size: Class I - arboreal strata, individuals with $\mathrm{CAP} \geq 30 \mathrm{~cm}$, evaluated in plots of $10 \mathrm{~m} \times 20 \mathrm{~m}$; Class II - arboreal strata, individuals with $15 \leq \mathrm{CAP}<30 \mathrm{~cm}$, in plots of $10 \mathrm{mx}$ $10 \mathrm{~m}$; Class III - established natural regeneration, woody individuals with $3 \leq \mathrm{CAP}<15 \mathrm{~cm}$, in plots of $5 \mathrm{~m} \times 5 \mathrm{~m}$; Class IV - bank of seedlings, individuals with height $\geq 30$ $\mathrm{cm}$ and $\mathrm{CAP}<3 \mathrm{~cm}$, in plots of $2 \mathrm{~m} \times 2 \mathrm{~m}$.

The botanical material of all the species observed was herborized in the Forest Herbarium from Department of Forest Sciences, from Federal University of Santa Maria (UFSM). The species were classified in the botanical families recognized by Angiosperm Phylogeny Group IV (Chase 2016), and the scientific binomials were updated according to Forzza et al. (2020).

The data of the forest catalogue originated a matrix parcel x species, formed by 57 plots (lines) and 34 species 
(columns), for the species with $\mathrm{CAP} \geq 30 \mathrm{~cm}$ (Class I), excluding the rare, considered with less than five individuals. Afterwards, the matrix was used in a multivariate analysis by TWINSPAN method (TWo-way INdicator SPecies ANalysis) (Gauch 1982), using the PC-ORD ${ }^{\mathrm{TM}}$ program for Windows, version 5.10. The use of this method allows the classification of groups of plots that characterize microhabitats, based on the density of individuals of the different species present. At each site, the indicator and preferred species of the environment are defined (Araujo et al. 2004). The method provides the explained variance, indicated by the division eigenvalue, which above 0.3 is considered to be of strong relevance in determining the data variation (Felfili et al. 2001). For attenuating the effects of the deviations provoked by very elevated values of abundance, there was the necessity of transformation of these ones, applying $\ln (\mathrm{a}+1)$, where " $\mathrm{a}$ " represents the number of individuals in each parcel (Carvalho et al. 2005).

The levels of cutting to characterize the pseudo-species were determined based on the densities observed for the species in each parcel, where 0 ( 0 or 1 individual), 2 ( 2 to 4), 5 (5 to 7 ), 8 (8 to 9), and 10 (10 or more individuals), representing the pseudo-species 1, 2, 3, 4 and 5, respectively. The formed groups were analyzed in relation to the floristic composition and structure, using parameters as density, dominance and absolute frequency, besides the percentage importance value (Felfili and Rezende 2003), seeking to define structural differences present in each place, based on the classes of size evaluated. In addition, according to the same authors, the diversity of species in community level was obtained by Shannon Diversity Index (H') and the equability $(\mathrm{J})$.

\section{RESULTS}

Considering all the classes studied, 65 species were sampled, belonging to 49 genera and 30 botanical families. Nevertheless, analyzing the species belonging to the arboreal strata (Class I: CAP $\geq 30 \mathrm{~cm}$ ), 755 individuals ha ${ }^{-1}$ of 51 species, 43 genera and 29 families were found. The Diversity Shannon index (H') was of 2.97, indicating low diversity associated with reduced equability $(\mathrm{J})(0.44)$, in response to the predominance of few species.

The classification by the TWINSPAN method divided the vegetation into three floristic groups. This way, the first division presented a self-value of 0.33 , originating the Group 1 (GR1). The second division, with a self-value of 0.34 , classified Groups 2 (GR2) and 3 (GR3). The group 1 , although belonging to Mixed Ombrophilous Forest, presented higher number of species characteristic of riparian forest. The group 2 represents a remnant of Mixed Ombrophilous Forest under the influence of intensive use of fields in livestock, while the group 3 represents an atypical situation of the region, with the predominance of Eucalyptus spp., used in the recovery of slope after the flooding of the dam, and also the occurrence of species strongly influen- ced by the depth of soil, as well as the hydric saturation in longer periods of time.

The groups formed in this study, with the respective plots, indicators and preferable species, can be visualized in figure 2. The indicator species of GR1 (formed by 34 plots) were Eugenia uruguayensis Cambess. and Myrsine coriacea $(\mathrm{Sw}$.) R. Br. both represented by pseudo-species 1, occurring in 29 and 15 plots, respectively. In GR2 (formed by 21 plots), there was not indicator species, and the group was defined by the preferable species: Blepharocalyx salicifolius (Kunth) O. Berg, Calyptranthes concin$n a$ DC. and Myrciaria delicatula (DC.) O. Berg with the pseudo-species 1. Myrceugenia cucullata D. Legrand with the pseudo-species 2, Araucaria angustifolia (Bertol.) Kuntze (pinheiro-brasileiro) and M. cucullata with the pseudo-species 3 and A. angustifolia also with the pseudo-species 4. The indicator species of GR3 (2 plots) was Symplocos uniflora (Pohl) Benth. represented by pseudospecies 2 (figure 2).

In the structure of GR1, approximately 815 individuals ha ${ }^{-1}$ belonging to 42 species, 36 genera and 24 botanical families were found. Among the species belonging to this group, considering the Class I $(\mathrm{CAP} \geq 30 \mathrm{~cm})$, the ones that presented the highest value of importance were A. angustifolia, Gymnanthes klotzschiana Müll.Arg., E. uruguayensis, Podocarpus lambertii Klotzsch ex Endl. and Lithraea brasiliensis Marchand, representing 51.6\% of the horizontal structure of this group (table 1).

In this study, $A$. angustifolia obtained superior prioritizing due to the elevated values of density (DA: 119.1 individuals ha- ${ }^{-1}$ ), dominance (DoA: $6.9 \mathrm{~m}^{2} \mathrm{ha}^{-1}$ ) and frequency (FA: $88.2 \%$ ) (table 1). While G. klotzschiana and E. uruguayensis, although the elevated values of density of 110.3 and 100 individuals ha $\mathrm{a}^{-1}$ and frequency of 64.7 and $73.5 \%$, presented low dominance $\left(3.3\right.$ and $\left.2.1 \mathrm{~m}^{2} \mathrm{ha}^{-1}\right)$, respectively.

Podocarpus lambertii and L. brasiliensis, however, presented another behavior, given the intermediate value for all the parameters (DA: 64.7 and 55.9 individuals ha ${ }^{-1}$; DoA: 3.5 and $2.9 \mathrm{~m}^{2}$ ha $^{-1}$; FA: 44.1 and $64.7 \%$, respectively). Despite the similar dominance in relation to the two species quoted before, P. lambertii and $L$. brasiliensis have a little more than half the number of individuals, proving their larger diametric size in the area of study.

In GR1, for the classes that represent the individuals of smaller dimensions (Classes II, III and IV) (table 1), A. angustifolia and P. lambertii are not present in the bank of seedlings (Class IV), besides being little represented in the established natural regeneration (Class III). Besides them, L. brasiliensis is absent in the classes of lower size (Classes III and IV).

For the species belonging to Group 2, 667 individuals ha $^{-1}$, belonging to 30 species, 26 genera and 17 families, were found. Among the species that presented the highest value of importance, there are A. angustifolia, P. lambertii, M. cucullata, L. brasiliensis and G. klotzschiana, representing $70.2 \%$ of the structure of the forest (table 1). 


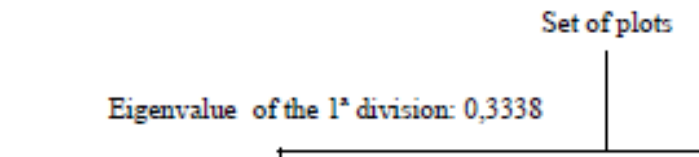

Group 1

Plots: 20, 21, 23, 24, 25, 27, 28, 30, 31, 32, 34,

$435,36,37,38,39,40,41,42,43,44,45,46,47$,

$48,49,50,51,52,53,54,55,56,57$.

Indicator species: Eugenia uruguayensis 1, Myrsine coriacea 1 .

Preferential species: Drymis 1 (12,0), E. urug. 1 $(29,4)$, Dex. bre $1(12,2)$, Myrcia p $1(11,0)$, Myrciant $1(7,2)$, Myrc. del $1(23,6)$, O. pul 1 $(12,4)$, Sebas. co $1(22,7)$, Styrax $1(7,1)$, Symp. uni $1(11,3)$, Zanthoxy $1(8,1)$, Drimys $2(9,0)$, E. urug $2(24,3)$, Lithraea $2(13,2)$ Myrc. del 2 $(17,2), \mathrm{M}$ coriac $2(7,0)$, Sebas. Co $2(13,2)$.

Abbreviations: Arauca: Araucaria angustifolia; Blepharo: Blepharocalyx salicifolius; Calyp: Calyptranthes concinna; Drymys: Drimys brasiliensis; E.gran: Eucalyptus grandis; E.salig: Eucalyptus saligna; E.urug: Eugenia uruguayensis; Ile.brev: Ilex brevicuspis; Lithraea: Lithraea brasiliensis; Myrcia p: Myrcia palustris; Myrciant: Myrcianthes gigantea; Myrc.cuc: Myrceugenia cucullata; Myrc.del: Myrciaria delicatula; M.coriac: Myrsine coriacea; O.pul: Ocotea pulchella; Podocar: Podocarpus lambertii;

Sebas.co: Sebastiania commersoniana; Styrax: Styrax leprosus; Symp.uni: Symplocos uniflora; Zanthoxy: Zanthoxylum rhoifolium;

Observation: The number after the abbreviation refers to pseudo-species (cutting level). The number in parentheses refers to parcels where the pseudo-species are, in both sides of the division.
Plots: 1, 2, 3, 4, 5, 6, 7, 8, 9, 10, 11, 12, 13, 14, $15,16,17,18,19,22,26,29,33$.

Indicator species: Podocarpus lambertii 2, Myrceugenia cuculiata 1.

Preferential species: Myrc. cuc 1 (10, 21), Podocar $1(16,22)$, Myrc. cue $2(5,13)$, Podocar 2 $(9,19)$, Myrc. cuc $3(0,5)$, Podocar $3(4,11)$, Arauca $4(0,5)$

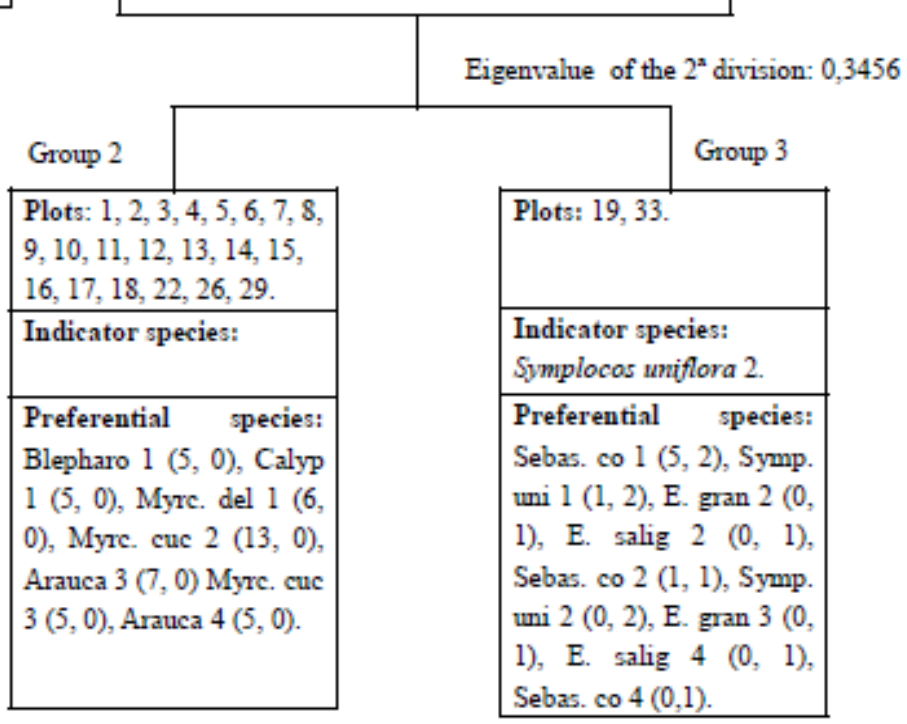

Figure 2. Classification of sampled units in three floristic groups for Class I (CAP $\geq 30 \mathrm{~cm}$ ), Mixed Ombrophilous Forest, RS, Brazil. Clasificación de las unidades muestreadas en tres grupos florísticos para Clase I (CAP $\geq 30 \mathrm{~cm}$ ), Bosque Umbrófilo Mixto, RS, Brasil.

Araucaria angustifolia and P. lambertii presented similarity among the evaluated parameters (table 1). In relation to $M$. cucullate, it is highlighted its presence in all the classes of size (table 1). Similarly to what was observed in GR1, L. brasiliensis is not represented in the classes of lower size (established natural regeneration and bank of seedlings) and G. klotzschiana, was absent in Class II.

In GR2, besides A. angustifolia and M. cucullata, it is worth to highlight Ocotea pulchella (Nees) Mez, Annona neosalicifolia $\mathrm{H}$. Rainer, C. concinna, M. delicatula and Myrciaria floribunda (West ex Willd.) O. Berg presented as "Others" in table 1 and which are well represented in all the classes, which will probably support their perpetuation throughout time. Likewise, noteworthy are Daphnopsis racemosa Griseb., Stillingia oppositifolia ex Müll.Arg., Rudgea parquioides (Cham.) Müll.Arg. and Rudgea jasminoides (Cham.) Müll. Arg. ("Others") as shrubby species, which are not found in Class I.

In Group 3, 675 individuals ha ${ }^{-1}$ belonging to six species, five genera and four botanical families (table 1) were found. The species better prioritized were P. lambertii, Eucalyptus saligna, A. angustifolia, G. klotzschiana and Eu- 


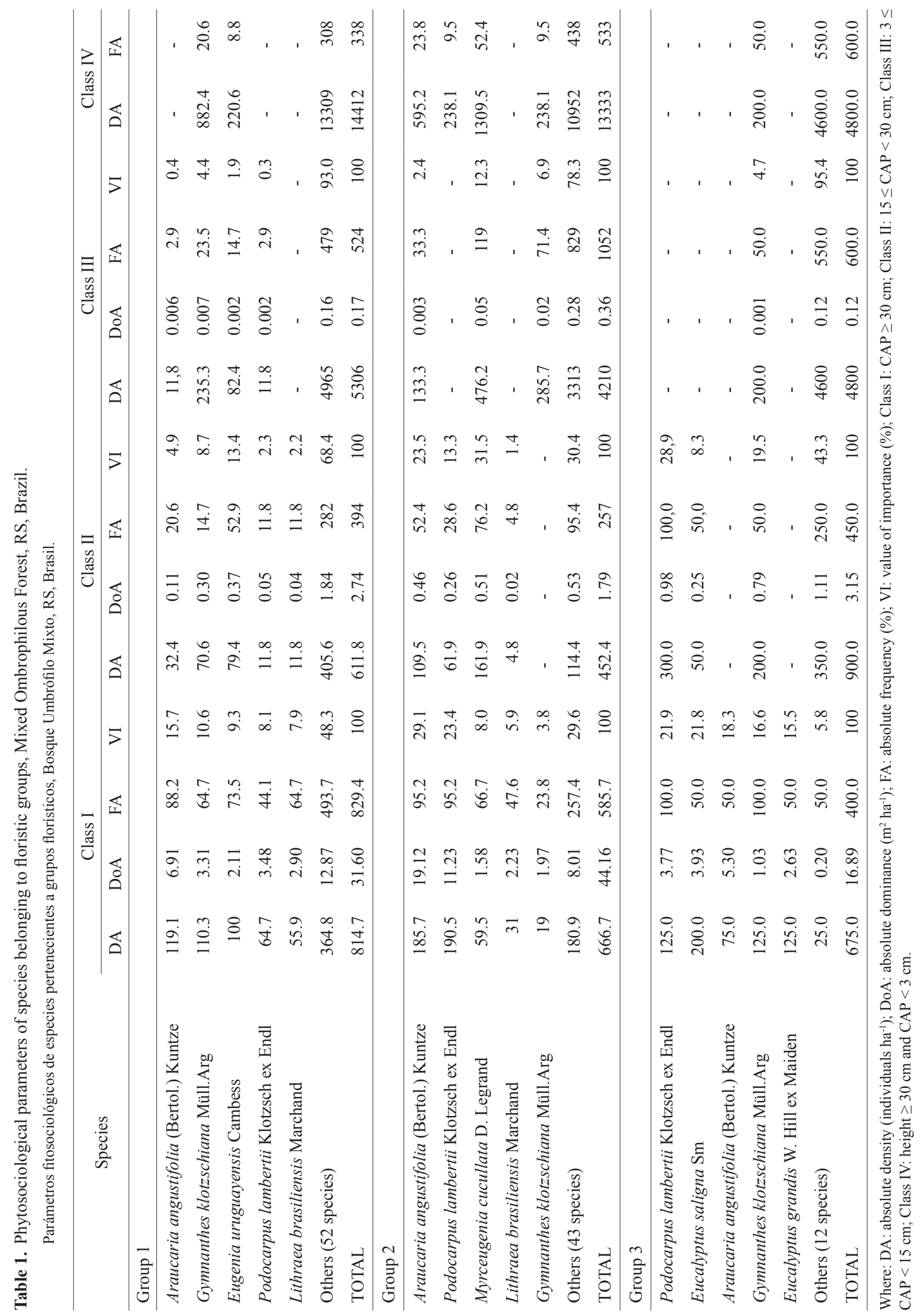


calyptus grandis Hill (ex Maiden). These species together sum up $94.1 \%$ of the horizontal structure, characterizing thus, the group under studying.

Among these species, the presence of $P$. lambertii and A. angustifolia (table 1) is characteristic of the formation in study (Mixed Ombrophilous Forest). Together with this, the presence of G. klotzschiana in all the classes confirms its environmental preference for riparian environments, with more important hydric saturation, as the situation found in this group.

\section{DISCUSSION}

The diversity and equability in class I, associated with the floristic richness are low values when compared with Araujo et al. (2010), who, evaluating the arboreal strata $(\mathrm{CAP} \geq 30 \mathrm{~cm})$ of a forest remnant in National Forest of Sao Francisco de Paula (FLONA), observed the presence of 86 species belonging to 60 genera and 34 families. This divergence is possibly related to the occupation history of the area and to the state of preservation of the remnants, having in mind that FLONA is a unit of conservation, in which there is low intensity of alteration. This is corroborated by Li et al. (2012), who report that the human activities change the standards of the vegetation distribution.

When analyzing the floristic composition of Class I $(C A P \geq 30 \mathrm{~cm})$ in $\mathrm{GR} 1$, values higher than those observed in GR2 were observed, both in structure and in floristic richness. In different clusters formed in vegetation of FLONA of Sao Francisco de Paula, Araujo et al. (2010) found in one of the groups, which was also characterized by the presence of species that are typical of riparian forest, 877 individuals.ha- ${ }^{-1}, 55$ species, 42 genera and 23 families. These results demonstrate the similarity of the studied environments in relation to structure (density), corroborating with Pagano and Durigan (2000), who described that in humid soils occurs elevated density of arboreal vegetation, however with richness expressively lower, possibly determined by the fragmentation of the areas and the lower flow of the dispersing fauna.

The GR2, although presents lower number of individuals (DA: 666.7 individuals ha ${ }^{-1}$ ) in relation to GR1 (DA: 814.7 individuals ha ${ }^{-1}$ ), has higher total basal area (DoA: $44.2 \mathrm{~m}^{2} \mathrm{ha}^{-1}$ ) when compared to GR1 (DoA: $31.6 \mathrm{~m}^{2} \mathrm{ha}^{-1}$ ) (table 1). This fact indicates the presence of individuals with diameter expressively larger in GR2, possibly due to the lower influence of water and the lower competition of the regenerating individuals, characterizing a structural difference of these two environments. Despite the best prioritization of $A$. angustifolia in GR1 (15.7\%), this was not an indicator, a fact explained by its expressive representativeness also in GR2, condition that is different from that of E. uruguayensis and M. coriacea, which occurred, basically, in GR1.

In GR1, the absence of $A$. angustifolia in the bank of seedlings (Class IV) and its low representativeness in es- tablished natural regeneration (Class III) diverge from the results found by Duarte et al. (2002) who observed the occurrence of this species in different levels of irradiance. A. angustifolia was classified as presenting pioneer behavior (Ferreira et al. 2013) until late secondary (Duarte et al. 2002), nevertheless, despite evincing this plasticity in its development in relation to the conditions of luminosity, this was not verified in the present study, considering the absence of the same in the low story.

Podocarpus lambertii, species classified as initial secondary and late secondary (Chami et al. 2011), also presented the same behavior as that seen in A. angustifolia in the classes of lower size (table 1). This confirms what described Backes (1983), when characterizing the stratification of vegetation of Mixed Ombrophilous Forest in four strata, being the second stratum formed predominately by P. lambertii, among other species.

Besides that, L. brasiliensis is not represented in the classes of smaller size (Classes III and IV) (table 1), however, in this case, this situation is attributed to the pioneer character of the species (Ferreira et al. 2013), indicating that in conditions of low light intensity, this species cannot thrive itself. Pioneer species emerge after disturbances that expose the soil to light, because their seeds, generally, present larger longevity (Swaine and Whitmore 1988).

This way, the absence of $L$. brasiliensis in the smaller classes indicates that without the canopy opening, this species has lower chance to remain in the forest. In the case of $A$. angustifolia, although it is also classified as pioneer (Ferreira et al. 2013), its presence only in the established natural regeneration allows inferring that the same does not have bank of seeds of soil, because it presents recalcitrant seeds (Araldi and Coelho 2015). Its perpetuation is assured by established natural regeneration; however, it depends on monitoring in the bank of seedlings.

On the other hand, G. klotzschiana and E. uruguayensis are well represented in all the studied classes, suggesting their higher possibility of conservation in the environment (GR1). This fact occurred probably due to their greater plasticity in relation to the conditions of luminosity, because they present behavior of heliophytic species, but also are considered pioneers to the late secondaries. Besides that, it is worth to highlight that both species present characteristics to occur in alluvial forests and gallery forests (Reitz et al. 1983), environments similar to the ones of GR1. Such phytosociological characteristics observed in G. klotzschiana and E. uruguayensis allow indicating them both to the enrichment of forests and to the recovery of areas of full sun, throughout the watercourses in the region.

In GR1, besides G. klotzschiana and E. uruguayensis, which are among the five ones better ranked and present in all the classes, it is worth to highlight $M$. delicatula, O. pulchella, Drimys brasiliensis Miers, B. salicifolius, Cinnamomum amoenum (Nees) Kosterm., Styrax leprosus Hook. et Arn., M. cucullata, C. concinna, Myrcia palustris 
DC., Zanthoxylum rhoifolium Lam., Roupala brasiliensis Klotzsch, Casearia decandra Jacq. and G. klotzschiana, which are among the species represented as "Others" (table 1), and that also present favorable situation for their perpetuation in this environmental condition (GR1). $D a$ phnopsis racemosa, $R$. parquioides, Miconia hiemalis A.St.-Hil. et Naudin ex Naudin and Miconia cinerascens Miq., cited as "Others", can also be highlighted as shrubby species, consequently, they were not found in the canopy of the forest. The elevated value of importance obtained in Class III (data not presented) is the best condition for these species, considering that they use different synusiae.

In GR2, absolute dominance was the main parameter that defined the hierarchy of A. angustifolia and P. lambertii (table 1). According to Carvalho (2003), the individuals of Brazilian-pine reach larger size, considering, besides the height, the diameter. Besides that, we highlight the fact that this species is presented in all the classes of size evaluated for this group. This fact was not verified for $P$. lambertii because it is absent in established natural regeneration (table 1). This fault occurred, probably, due to past events that were not explained by the punctual analysis, they can only be proven in studies of dynamics.

Myrceugenia cucullata, which was present in all the classes, belongs to the ecological group of initial secondaries to late secondaries (Chami et al. 2011), proven by the phytosociological parameters, which in Class II presented higher values in relation to Class I, indicating the best development of these individuals even under the canopy, a condition with more important intensity of shading. Gymnanthes klotzschiana was not sampled in Class II, which is possibly associated with wood extraction, since the species is an excellent producer of firewood and coal, with elevated calorific power (Carvalho, 2003), a fact confirmed by local residents who affirmed the removal of individuals of this species for this purpose.

However, when comparing the species in Class I with higher value of importance in GR1 and GR2, it was observed that, with exception of E. uruguayensis and M. сисиllata, all the other species are among the most representative in both groups. Such fact indicates that the groups formed, although they present structural characteristics considerable peculiar, present similar floristic composition, representing the typical field-forest transition.

On the other hand, we observe in GR1, besides the larger total number of individuals, the larger proportion of species occurring in all the classes of size $(8.7 \%)$, in relation to GR2 (3.4\%), which indicates the negative influence of the presence of cattle in the classes of smaller size for this group.

Yet, GR3 is different from the others due to the presence of exotic species, besides the presence of species that are strongly influenced by the deepness of soil, characterized exclusively in these plots as Cambisol, as well as by the hydric saturation. The presence of exotic species, among the most representative ones, is worth to be highlighted, because the process of dispersion of an exotic species can result in the expansion of the area of its occurrence. In this case, when the exotic species starts to dominate the environment provokes negative effects in the place, a fact that in the original condition was not evinced. This way, a possible eradication of this exotic species must be evaluated, because the bank of seeds under action of higher luminosity can germinate and thus increase the presence of the species in the area.

Although the High Altitude Fields and the few remnants of Mixed Ombrophilous Forest are being strongly pressured due to, mainly, the advance of cyclical cultures, pastures, livestock and cultivation of Pinus and Eucalyptus genera (Pillar et al. 2009), the catalogue did not show species of Pinus genera in none of the classes catalogued, indicating that the species, even being considered as invasive, is not compromising the vegetation of the areas under study. However, because it is a heliophytic species that needs high light intensity to develop similar to Eucalyptus spp., it is fundamental the maintenance of the forest fragments avoiding the entrance of seeds by anemochoric dispersion and its consequent germination and establishment in the interior of these fragments.

\section{CONCLUSIONS}

The forest fragments about Campos de Cima da Serra presented low floristic richness of typical species of Mixed Ombrophilous Forest. From this typical environment we highlight two main groups, one characteristic of riparian forest and the other of capões ${ }^{1}$.

In riparian forests (GR1), Eugenia uruguayensis and Gymnanthes klotzschiana stand out. In capões (GR2), the predominant species were Araucaria angustifolia, Podocarpus lambertii and Myrceugenia cucullata.

In riparian forests, the mixture of species from different ecological groups demonstrates that the forest is in a dynamic process of succession. GR2 (capões) presents negative influence of cattle in its composition and structure.

The condition of species in different classes associated with their ecological characteristics allows identifying possible strategies for the perpetuation of the arborealshrubby component of population and management of fragments aiming at its conservation.

\section{REFERENCES}

Adel MN, H Pourbabaei, DC Dey. 2014. Ecological species group - Environmental factors relationships in unharvested beech forests in the north of Iran. Ecologial Engineering 69: 1-7. DOI: https://doi.org/10.1016/j.ecoleng.2014.03.008

Alvares CA, JL Stape, PC Sentelhas, JLM Gonçalves, G Sparovek. 2013. Köppen's climate classification map for Brazil. Meteorologische Zeitschrift 2: 1-18. DOI: https://doi. org/10.1127/0941-2948/2013/0507

\footnotetext{
${ }^{1}$ Capões: are true islands of shrub-tree vegetation that stand out in the landscape.
} 
Araldi CG, CMM Coelho. 2015. Establishment of post-harvest early-developmental categories for viability maintenance of Araucaria angustifolia seeds. Acta Botânica Brasílica 29(4): 524-531. DOI: https://doi.org/10.1590/010233062015abb0061

Araujo MM, SJ Longhi, DA Brena, PLC de Barros, S Franco. 2004. Análise de agrupamento a vegetação de um fragmento de Floresta Estacional Decidual Aluvial, Cachoeira do Sul, RS, Brasil. Ciência Florestal 14(1): 133-147.

Araujo MM, L Chami, SJ Longhi, AL de Avila, DA Brena. 2010. Análise de agrupamento em remanescente de Floresta Ombrófila Mista. Ciência Florestal 20(1): 1-18. DOI: https:// doi.org/10.5902/198050981755

Backes A. 1983. Dinâmica do pinheiro brasileiro. Iheringia 30(1): 49-84.

Carvalho DA, ATF Oliveira, EA Vilela, N Curi, EVD Berg, MAL Fontes, L Botezelli. 2005. Distribuição de espécies arbóreoarbustivas ao longo de um gradiente de solos e topografia em um trecho de floresta ripária do Rio São Francisco em Três Marias, MG, Brasil. Revista Brasileira de Botânica 28(2): 329-345. DOI: https://doi.org/10.1590/S0100$\underline{84042005000200013}$

Carvalho PER. 2003. Espécies arbóreas brasileiras. Brasília, Brasil. Embrapa Informações Tecnológicas. 1039 p.

Chami LB, MM Araujo, SJ Longhi, P Kielsei, AD Lúcio. 2011. Mecanismos de regeneração natural em diferentes ambientes de remanescente de Floresta Ombrófila Mista, São Francisco de Paula, RS. Ciência Florestal 41(2): 251-259. DOI: https://doi.org/10.1590/S0103-84782011000200012

Chase MW. An update of the Angiosperm Phylogeny Group classification for the orders and families of flowering plants: APG IV. Botanical Journal of the Linnean Society 2016: 181(1): 1-20. DOI: https://doi.org/10.1111/boj.12385

Dengler J, M Chytrý, J Ewald. 2008. Phytosociology. In Jorgensen SE and BD Fath eds. Encyclopedia of Ecology. Oxford, UK. Elsevier. p. 2767-2779.

Duarte LS, LR Dillenburg, LM Rosa. 2002. Assessing the role of light avaliability in the regeneration of Araucaria angustifolia (Araucaricaceae). Australian Journal of Botany 50(1): 741-751. DOI: https://doi.org/10.1071/BT02027

Felfili JM, AC Sevilha, MC da Silva Júnior. 2011. Comparação entre as unidades fisiográficas Chapada Pratinha, Veadeiros e Espigão Mestre do São Francisco. In Felfili JM, MC da Silva Júnior eds. Biogeografia do Bioma Cerrado: estudo fitofisionômico na Chapada do Espigão Mestre do São Francisco. Brasília, Brasil. UNB. p. 80-94.

Felfili JM, RP Rezende. 2003. Conceitos e métodos em fitossociologia. Brasília, Brasil. Comunicações Técnicas Florestais. $68 \mathrm{p}$.

Ferreira PI, JP Gomes, F Batista, AP Bernardi, NCF Costa, RLC Bortoluzzi, A Mantovani. 2013. Espécies potenciais para recuperação de áreas de preservação permanente no Planalto Catarinense. Floresta e Ambiente 20(6): 172-182. DOI: http://dx.doi.org/10.4322/floram.2013.003

Forzza RC, AF Costa, BMT Walter, C Bicudo, CWN Moura, DF
Peralta, D P da Costa,F de Barros, HCe de Lima, J Prado, JR Stehmann, JFA Baumgratz, JR Pirani, LS Sylvestre, LC Maia, LG Lohmann, L Paganucci, M Nadruz, MCH Mamede, ML Soares, MR Barbosa, M Menezes, MP Morim, N Roque, PHL Evangelista, PL Viana, R Goldenberg, R Secco, T Cavalcanti, V Mansano, VC Souza. 2020. Flora do Brasil 2020. Assess mar. 2020. Available from: http://floradobrasil.jbrj.gov.br/reflora/PrincipalUC/PrincipalUC.do ;jsessionid=99EBD3DA3ED8523FE621D580EDD95759

Gauch HG. 1982. Multivariate analysis in community ecology. Cambridge, UK. Cambridge University Press. 180 p.

Goebel PC, BJ Palik, LK Kirkman, MB Drew, L West, DC Pederson. 2001. Forest ecosystems of a Lower Gulf Coastal Plain landscape: multifactor classification and analysis. Journal of Torrey Botanical Society 128(1): 47-75. DOI: https://doi. org/10.2307/3088659

Higuchi P, AC Silva, TS Ferreira, ST Souza, JP Gomes, KM Silva, KF Santos, C Linke, PS Paulino. 2012. Influência de variáveis ambientais sobre o padrão estrutural e florístico do componente arbóreo, em um fragmento de Floresta Ombrófila Mista Montana em Lages, SC. Ciência Florestal 22(1): 79-90. DOI: https://doi.org/10.5902/198050985081

Li J, S Dong, Z Yang, M Peng, S Liu, X Li. 2012. Effects of cascade hydropower dams on the structure and distribution of riparian and upland vegetation along the middle-lower Lancang-Mekong River. Forest Ecology and Management 284: 251-259. DOI: https://doi.org/10.1016/j.foreco. 2012.07 .050

Pagano SN, G Durigan. 2000. Aspectos da ciclagem de nutrientes em matas ciliares do Oeste do Estado de São Paulo, Brasil. In Rodrigues RR, HF Leitão Filho eds. Matas ciliares: conservação e recuperação. São Paulo, Brasil. EDUSP/FAPESP. p. 109-123.

Pillar VP, SC Müller, ZMS de Castilhos, AVA Jacques. 2009. Campos Sulinos - conservação e uso sustentável da biodiversidade. Brasília, Brasil. Ministério do Meio Ambiente. 409 p.

Pajares PR, RE Rosselo. 1995. Natural black pine (Pinus nigra subsp. salzmannii) forest of Iberian eastern mountains: development of the phytoeco-logical basis for their site evaluation. Annals of Forest Science 52: 589-606. DOI: https://doi.org/10.1051/forest:19950606

Reitz R, RM Klein, A Reis. 1983. Projeto Madeira do Rio Grande do Sul. Itajaí, Brasil. Sellowia. 525 p.

Streck EV, N Kämpf, RSD Dalmolin, E Klamt, PC do Nascimento, P Scheneider, E Giasson, LFS Pinto. 2008. Solos do Rio Grande do Sul. Porto Alegre, Brasil. EMATER/RSASCAR. 222 p.

Swaine MD, TC Whitmore. 1988. On the definition of ecological species groups in tropical rain forests. Vegetation 75: 81-86. DOI: http://dx.doi.org/10.1007/BF00044629

Vibrans AC, AL Gasper, JJV Müller. 2012. Para que inventariar florestas? Reflexões sobre a finalidade do inventário florístico florestal de Santa Catarina. Revista de Estudos Florestais 14 (1): 6-13. DOI: http://dx.doi.org/10.7867/1983$\underline{1501.2012 \mathrm{v} 14 \mathrm{n} 1 \mathrm{p} 6-13}$ 